https://www.journal-imab-bg.org

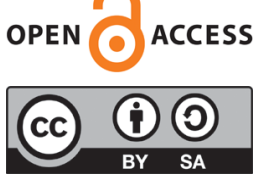

Case report

\title{
TREATMENT OF TRAUMATIZED MAXILLARY PERMANENT CENTRAL INCISORS. A CASE RE- PORT
}

\author{
Radosveta S. Andreeva \\ Department of pediatric dentistry, Faculty of Dental Medicine, Medical Uni- \\ versity, Varna, Bulgaria.
}

\begin{abstract}
:
Traumatic injury to the upper anterior teeth is common in young children, especialy when it is combined whit orthodontic problem - overjet. This paper reports the presence of traumatized maxillary permanent central incisors which are successfully restored whit wax-up technique.

Case report: The case describe the treatment of traumatized maxillary permanent central incisors whit wax-up technique. A 9-year-old girl came to the dental clinic with an injury of the two maxillary central incisors with oblique partial crown fracture without pulp exposure. Traumatized anterior teeth require quick functional and esthetic repair, and wax-up technique is commonly used for their restoration. The wax-up technique seems to be a promising restorative option. This is a rational restorative alternative and less invasive prosthodontic treatment. The patient and the parents are satisfied whit the result which confirmed the success of the rehabilitation.
\end{abstract}

Keywords: incisors, trauma, wax-up technique, aesthetics, crown fracture

\section{INTRODUCTION}

One of the most serios and frequent oral problems in children is dental trauma. The most frequqnt traumas in shildren are enamel fracture, luxation and non-complicated enamel-dentin fracture. The traumas are caused most often from sports and accidents. Dental injuries can cause functional disorders, physiological and aesthetic problems. One of the challenges to the dentist is the aesthetic rehabilitation of crown fractures ot the front maxillary theeth. Traumatic injury to the upper anterior teeth is common in young children, especialy when it is combined whit orthodontic problem - overjet. The wax-up is not expensive and simple. In order to build-up the palatal surfaces of the anterior teeth the most accurate technique is wax-up. The dentist can control the entire process of this technique. Maxillary incisive coronary fractures are the most common traumatic injuries of permanent teeth in children, which is a public health problem $[1,2,3,4,5]$. They represent damaged hard dental tissues of the dental crown $[6,7,8]$. They are also one of the leading causes of emergencies in dental medi- cine. Incisive fractures cause both physical and psychological discomfort. They are accompanied by pain, impaired chewing function and aesthetics. This affects the quality of life and social contacts of children with such kind of traumas $[9,10]$.

\section{BACKGROUND:}

Diagnosis and treathment planning: A 9-year-old girl came to the dental clinic with an injury of the two maxillary central incisors with oblique partial crown fracture without pulp exposure, while riding a bike (Fig. 1).

Fig. 1. Uncomplicated trauma of central incisors.

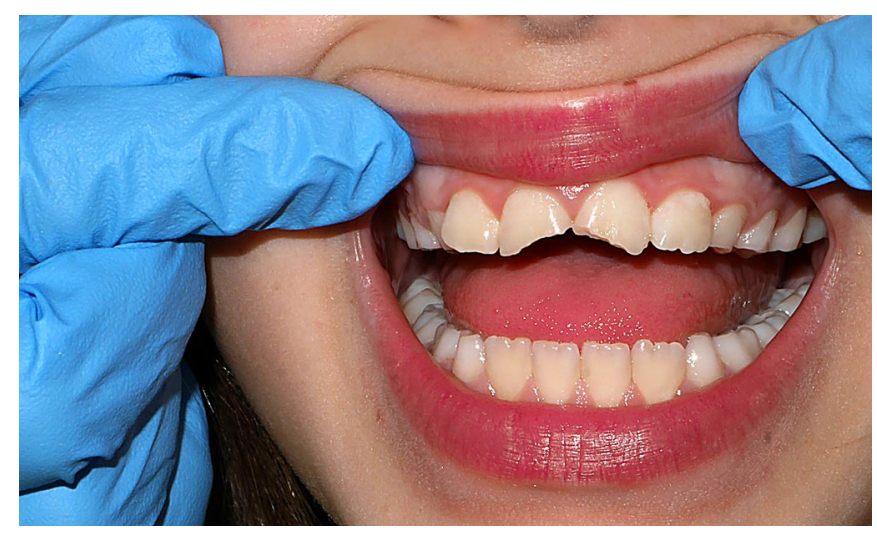

Before the dental trauma, the injured teeth were completely intact and healthy, in a correct position in the dental arch.

\section{CASE DESCRIPTION:}

The patient had some subjective symptoms - the fractured teeth were sensitive to thermal stimuli.

Objective symptoms - there was missing part of the crown, the pulp was not exposed. In order to prevent the pain and pulp infection, we made temporary restoration with Glass-ionomer cement (GJC), after taking an impression of the upper jaw. The impression was taken to the dental laboratory, where the silicon index on gypsum casts was fabricated (Fig. 2). 
Fig. 2. Fabrication of silicone index on gypsum cast.

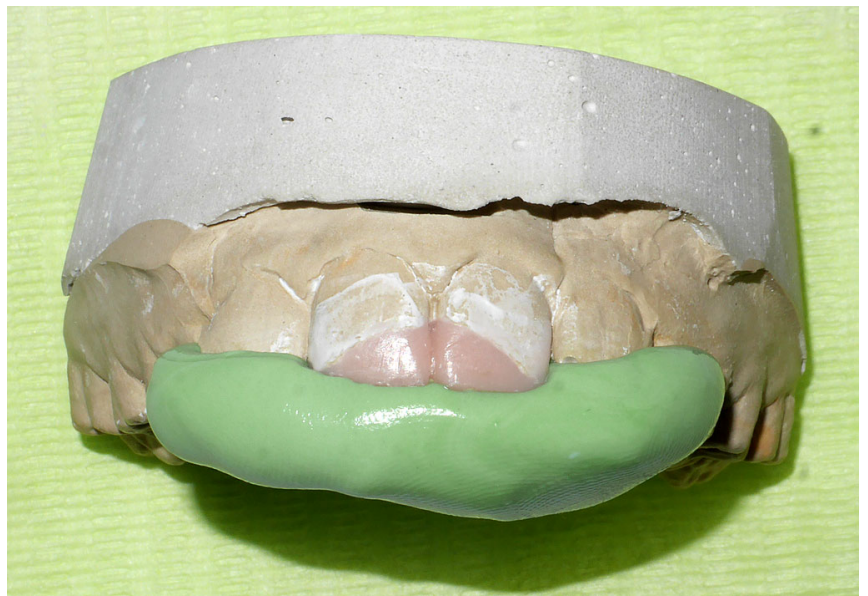

Vitality test was negative at the first examination, 2 hours after the trauma, after 10 days - vitality test became positive. Radiography was made- the condition of the periodontal ligament was normal, and the fracture line was near, but not reaching the pulp and root development was completed (Fig. 3).

Fig. 3. Diagnostic X-ray.

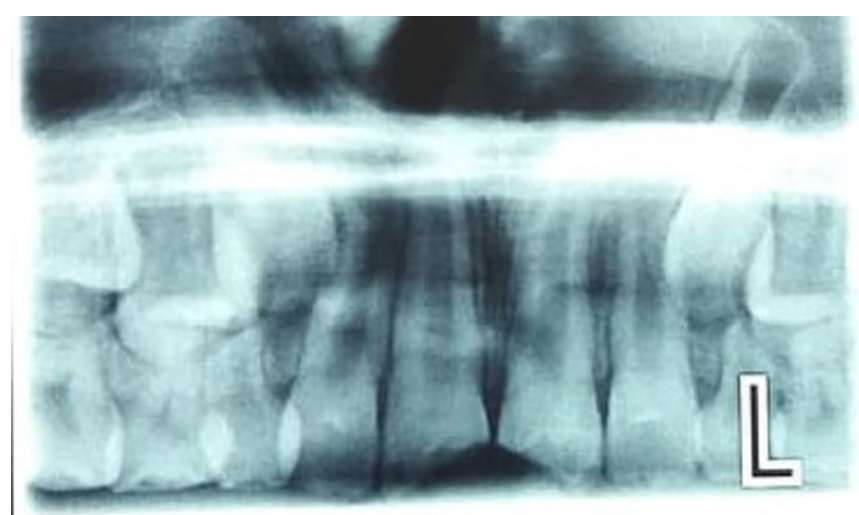

During the second visit, after the vital test (positive) and the removal of the temporary restoration, the wax-up technique was done. The exposed dentin was covered with $\mathrm{Ca}(\mathrm{OH}) 2$-cement, before the restoration (Fig. 4).

Fig. 4. The exposed dentin was protected with $\mathrm{Ca}(\mathrm{OH}) 2$, prior to restoration.

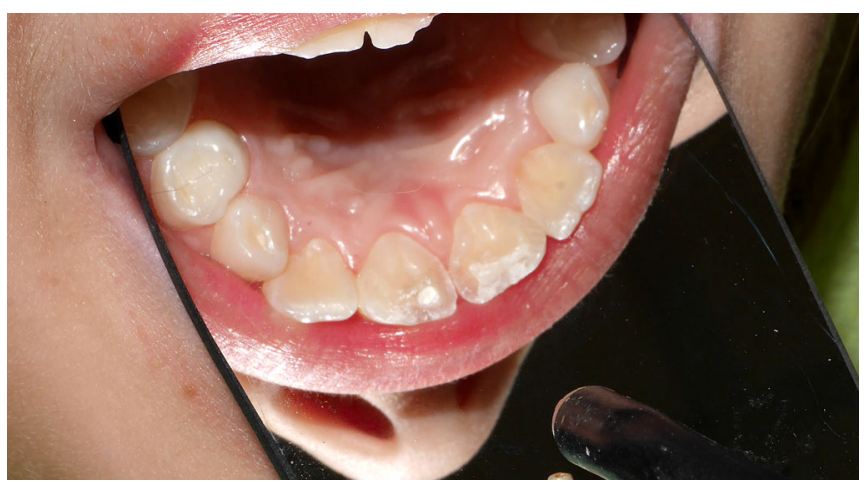

The esthetic restoration was made of a universal composite (Figures 5, 6, 7 and 8).

Fig. 5. Teeth build up with the aid of silicone index.

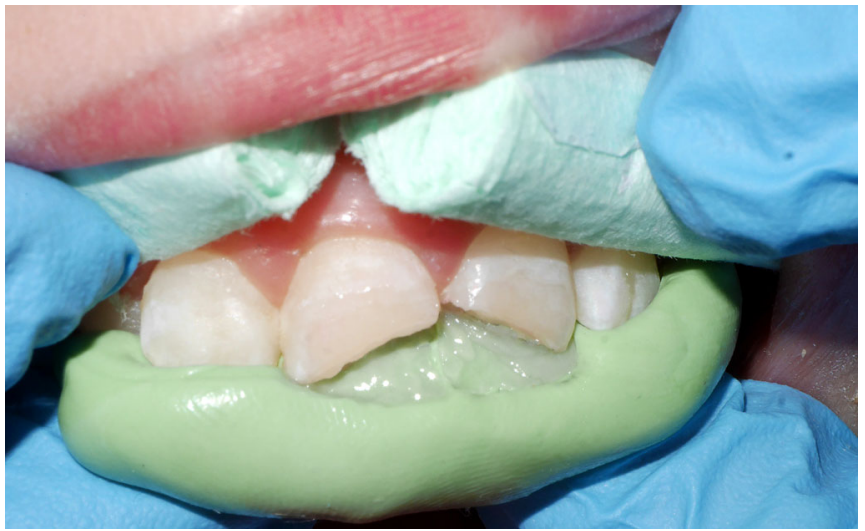

Fig. 6. Restoration of the teeth with a composite by layers.

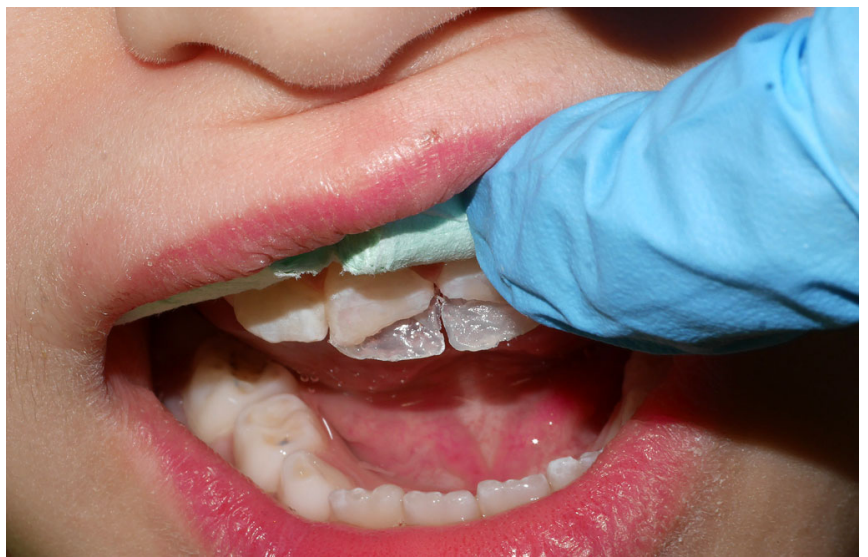

Fig. 7. Polishing.

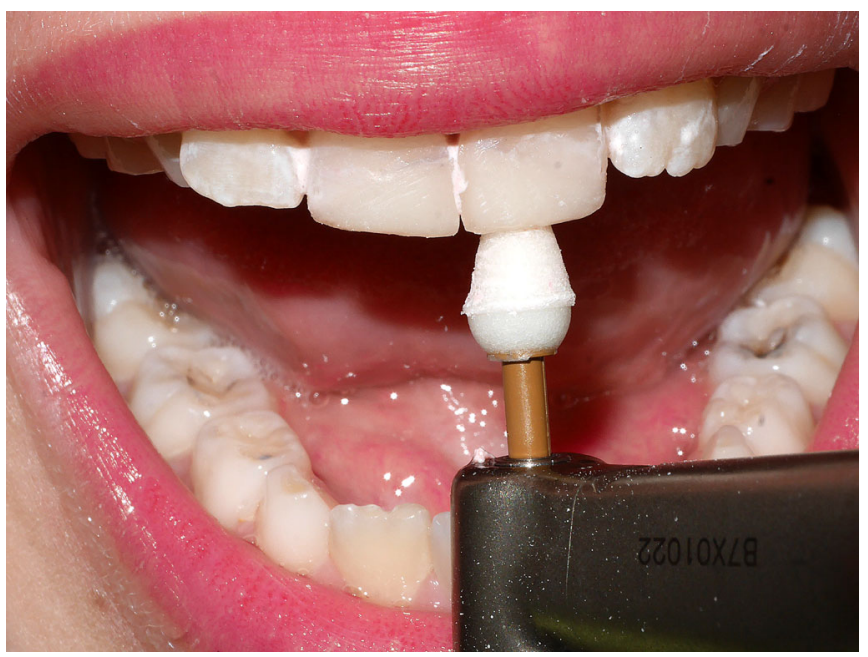


Fig. 8. Final result.

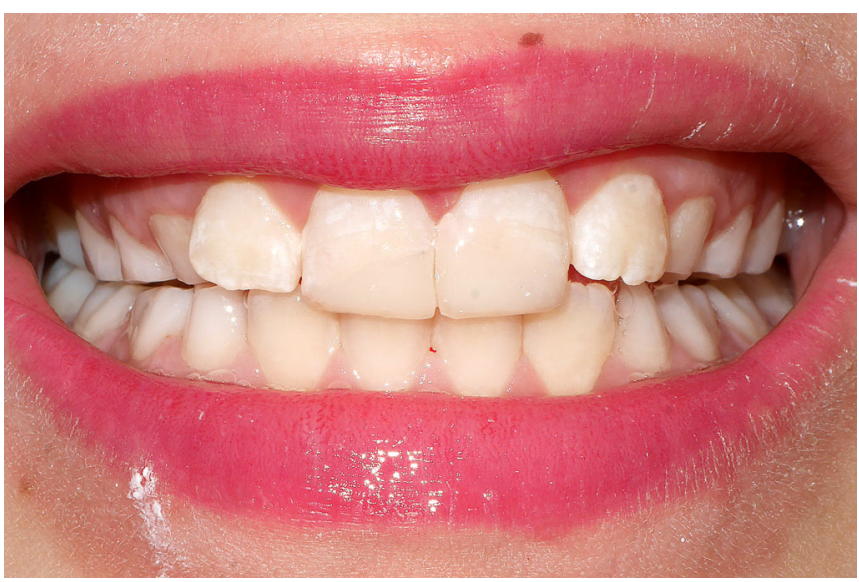

The case was followed up. Two years after the trauma, the teeth were vital, and the restoration was preserved.

\section{DISCUSSION:}

Maxillary incisors are the most commonly involved teeth in dental trauma, and dental crowns are frequently damaged because of their exposed position in the dental arch. When there is a dental trauma of the frontal teeth we have to achive a good aesthetic and occlusal relationship. This could be done by some techniques: direct restorations and indirect restorations. When indirect restorations are used more heathy tissues are lost because ot the need of the preparation ot the teeth. When direct restorations are used we preserve the heathy tissues and this techniques are not so invasive like the indirect restorations. Traumatized anterior teeth require quick functional and esthetic repair, and wax-up technique is commonly used for their restoration. In the case of uncomplicated crown fracture, without pulp exposure, the wax-up technique was used to prevent bacterial infection of the pulp and to restore the missing part of the teeth esthetically $[11,12]$. By a precise restoration of the dental morphology, an adequate function and aesthetic could be achieved. Instead of the needs of esthetic restoration and function, the pulp has to be preserved alive. $\mathrm{Ca}(\mathrm{OH}) 2$-cement has a success rate as a pulp protecting agent in such kind of traumas. In order to have restorations with optimal mechanical, biological and aesthetic properties, layers of conventional composites do not exceed $2 \mathrm{~mm}$ thickness, since layers thicker than $2 \mathrm{~mm}$. cannot polymerise properly. The universal light curing composite that is used for the wax-up technique has been placed with this incremental placement technique $[12,13]$. The usage of the wax-up technique is becoming widespread. Being aware of indications and contraindications will improve the clinicians' ability to predict success. The correct clinical technique is essential for optimal performance of these wax-up restorations and ultimately parental and clinicians satisfaction [13]

\section{CONCLUSION:}

In modern dentistry more conservative restorations and non-invasive techniques, in order to maintain tooth integrity at an optimum level, are preferred. Based on this case the wax-up technique can be recommended for restoration of traumatised anteriore teeth. The wax-up technique seems to be a promising restorative option. This is a rational restorative alternative and less invasive prosthodontic treatment.

\section{REFERENCES:}

1. Beltcheva A. [Crown fractures of permanent teeth in children.] Plovdiv Medical Press. 2009, p.5. [in Bulgarian]

2. Petti S. Over two hundred million injuries to anterior teeth attributable to large overjet: A meta-analysis. Dent Traumatol. 2015; 31(1):1-8 [PubMed] [Crossref]

3. Al Ansary MA, Day PF, Duggal MS, Brunton PA. Interventions for treating traumatized necrotic immature permanent anterior teeth: inducing a calcific barrier and root strengthening. Dent Traumatol. 2009 Aug;25(4):36779. [PubMed] [Crossref]

4. Rozi AH, Scott JM, Seminario AL. Trauma in Permanent Teeth: Factors Associated With Adverse Outcomes in a University Pediatric Dental Clinic. J Dent Child (Chic). 2017 Jan 15;84(1):9-15. [PubMed]
5. Atabek D, Alacam A, Aydintug I, Konakoglu G. A retrospective study of traumatic dental injuries. Dent Traumatol. 2014 Apr;30(2):154-61. [PubMed] [Crossref]

6. Wallace A, Rogers HJ, Zaitoun H, Rodd HD, Gilchrist F, Marshman Z. Traumatic Dental Injury Research: On Children or With Children? Dent Traumatol. 2017 Jun;33(3):153-159. [PubMed] [Crossref]

7. Ghouth N, Duggal MS, Nazzal H. The use of dental pulp tests in children with dental trauma: a national survey of the British Society of Paediatric Dentistry's members. Br Dent J. 2019 Feb 1;226:207-212. [PubMed] [Crossref]

8. Day PF, Duggal MS, High AS, Robertson A, Gregg TA, Ashley PF, et al. Discoloration of teeth after avulsion and replantation: results from a multicenter randomized controlled trial. J Endod. 2011 Aug;37(8):1052 7 [PubMed]

9. Dua R, Sharma S. Prevalence, causes, and correlates of traumatic dental injuries among seven-to-twelveyear-old school children in dera bassi. Contemp Clin Dent. 2012 Jan;3(1):3841 [PubMed] [Crossref]

10. Al-Jundi SH. Type of Treatment, Prognosis, and Estimation of Time Spent to Manage Dental Trauma in Late Presentation Cases at a Dental Teaching Hospital: A Longitudinal and Retrospective Study. Dent Traumatol. 2004 Feb;20(1):1-5. [PubMed] [Crossref]

11. Day PF, Gregg TA, Ashley P, Welbury RR, Cole BO, High AS, et al. Periodontal healing following avulsion and replantation of teeth: a multicentre randomized controlled 
trial to compare two root canal medicaments. Dent Traumatol. 2012 Feb;28(1):55-64. [PubMed] [Crossref]

12. Rodd H, Noble F. Psychosocial Impacts Relating to Dental Injuries in
Childhood: The Bigger Picture. Dent injuries to permanent dentition and its $J$ (Basel). 2019 Mar 4;7(1):23. association with overjet in a swiss [PubMed] [Crossref] child population. Dent Traumatol. 13. Schatz JP, Hakeberg M, Ostini 2013 Apr;29(2):110-4. [PubMed] E, Kiliaridis S. Prevalence of traumatic [Crossref]

Please cite this article as: Andreeva RS. Treatment of traumatized maxillary permanent central incisors. A case report. $J$ of IMAB. 2020 Jul-Sep;26(3):3241-3244. DOI: https://doi.org/10.5272/jimab.2020263.3241

Received: 17/03/2020; Published online: 16/07/2020

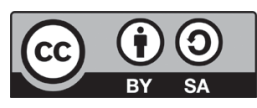

\section{Address for correspondence:}

Assoc. Prof. Radosveta Andreeva-Borisova, PhD, DsC

Department of pediatric dentistry, Faculty of Dental Medicine, Medical University, Varna,

84, Tsar Osvoboditel Blvd., Varna, Bulgaria

E-mail: doctor_ra@abv.bg, 